Article

\title{
Perspective: Stabilizing the Microbiome Skin-Gut-Brain Axis with Natural Plant Botanical Ingredients in Cosmetics
}

\author{
Kavita Beri ${ }^{1,2,3}$ \\ 1 BE MIND BODY SKIN, Integrative Aesthetics Ocean Township, NJ 07712, USA; beri.kavita@gmail.com \\ Department of Biomedical Engineering, the State University of New Jersey, Piscataway, NJ 08854, USA \\ 3 Center for Dermal Research, New Jersey Center for Biomaterials, Rutgers University, Piscataway, NJ 08854, USA
}

Received: 9 May 2018; Accepted: 9 June 2018; Published: 13 June 2018

\begin{abstract}
The microbiome of the gut and skin have recently been shown to have a strong connection through the host immune system. Various skin and gut inflammatory conditions are interrelated and connected through intricate immune pathways that affect the host barrier functions both in the skin and the gut. Microbiome 'dysbiosis' of the skin and gut leads to various alterations in host immune pathways that can alter the barrier and lead to disease. In this perspective article, we discuss the role of plant botanicals in cosmetics and their effect on the skin-gut-brain axis.
\end{abstract}

Keywords: microbiome; skin-gut-brain axis; plant botanical ingredients

\section{Introduction}

The surface microbiome opens a new dimension in looking at the very intricate communication between the external environment and the human body [1]. With a unique signature to each host, the microbiome forms a cloud of microorganisms that have specific interactions with each other and with the immune system of the host. The neuroendocrine and immune pathways of the host play an important role in establishing communication between the microbial commensals and the internal host organs in a skin-gut-brain axis [2]. The human body perhaps can be looked at as being $40 \%$ human cells to about $60 \%$ bacterial microorganisms [3]. This fact leads us to take a more serious interest in how these microorganisms interact with their specific host to impact the regulatory functions of the host [4].

\section{Microbiome-Host Interaction through Immune System}

Microorganisms are present from the surface to the deeper layers of the skin as well as in the epithelial lining of the gut. The specificity of microorganisms to each host as elucidated through metagenomic sequencing has led to the recognition of the microbiome as a unique signature to each host [4]. Several factors have been implicated in affecting the surface microbial colonies both on the skin and in the gut, from birth to environmental changes, geographic location, and dietary changes as well as a modern lifestyle [5]. A shift towards more immunological health conditions affecting the population, e.g., allergies, autoimmune conditions, atopic skin conditions, etc. can be attributed to these factors, which can influence the host and microbial interaction [5]. It can be inferred that between the bacterial organisms and the host surface cells there exists a symbiotic relationship. A harmonious balance between their communication exists in a physiologic state. A "dysbiotic" state adversely impacts physiological functions such as barrier protection, and may therefore lead to pathologic states. The immune cells in the surface layer are primarily the mediators of this communication in the host through a complex immune signaling pathway. Both the innate and adaptive immune system play a 
role in this dialogue, affecting the various host immune organs like the lymph nodes, liver, and spleen as well as creating an interaction between the gut and skin [1,5]. Detailing the interaction of the host immune system and microorganisms is beyond the scope of this publication. However, several recent papers have elaborated the major role of Toll-like receptor (TLR) cells, dendritic cells, natural killer cells (NK cells), and Langerhans cells in microbial interactions and in passing on the effects of these interactions through an immunological cascade in the host [1-5].

\section{Elaborating the Skin-Gut-Brain Axis and Various Host Neuroendocrine Pathways}

Possible immunologic connections between the skin and the gut can be seen in conditions such as celiac disease, which often has an associated dermatitis, and psoriasis, where gut-associated bacteria can be more frequently found circulating in the bloodstream [6,7]. A study recently published in 2018 by Codoner et al. in Nature Scientific Reports presented data that showed a "psoriatic core intestinal microbiome" exists that clearly differs from the one present in the healthy population. They also reported that these patients had a higher incidence of gut to blood stream translocations of microbial components with poor immune and barrier functions in the gut. Recent findings have also indicated the effect of gut microbiome on atopic dermatitis [7,8].

Gut and skin both have a neuroendocrine pathway that influences the brain function. For example, dysbiosis of the skin and gut microbes in atopic dermatitis has been connected to mental states such as depression and anxiety [9]. An established gut-brain axis is understood by the communication through multiple parallel pathways including the autonomic nervous system as well as the pituitary-hypothalamus-adrenal axis [9]. In a recent publication, the author emphasized the role of gut bacteria in aiding the delivery of nutrients needed for absorption, for example, complex oligosaccharides that need gut microbes for processing, which then helps with the absorption of minerals like calcium, magnesium, and iron from the gut [10]. These nutrients are responsible for physiological effects such as protecting the gastric mucosa, improving emotional state, supplying energy in the sleeping state, and modulating subsequent behavior, leading to brain activation and behavioral modulation in response to signaling through the gut-brain axis $[9,10]$. Complex oligosaccharides, essential amino acids, and various minerals are absorbed in the gut with the help of healthy gut flora [10]. Certain factors that were noted to alter gut bacteria, for example in terms of biodiversity, include animal-based foods and products where the animal source was treated with antibiotics and hormones [11]. Plant-based foods have shown a positive influence on moderate acne vulgaris, the treatment of which up until now has been through antibiotics [11].

\section{Plant Botanicals that Affect Gut and Skin}

Not much data is available in the field of specific botanicals regarding their role on the skin microbiome, however, there is evidence of a plant-based diet being beneficial for gut microbiome [11,12]. Given the important relationship between the skin and gut microbiome and the noted impact of plant-based diets on gut health, we can speculate that plant-based topicals in cosmetics may also act as a healthy source of nutrients for the skin microbiome and perhaps overall health.

Plants are equipped with regenerative and inflammatory pathways of their own involving potent antioxidants, phyto-acids, oleic compounds, and reactive byproducts that have been shown to have positive effects on human tissue [12,13]. Plant stem cells in cosmetics have become popular in topical formulations. Modern extraction methods have been used to obtain potent compounds from plant callus cells that have shown some anti-aging benefits [13]. It is worth considering, however, that processing, just as in food, may alter and perhaps have detrimental effects on the living plant extracts [14-17].

Ayurveda and Siddha medicine have used potent natural herbs to treat many ailments. These ancient medical systems that originated perhaps five thousand years ago in India, believe that a harmonious state of being is achieved when the personal constitution, or Dosha, is balanced with its surroundings [18]. An interrelationship is postulated between personal composition (also known as 
the "Dosha") and the environment. It is interesting to consider the similarities of this concept with that of the microbiome and host [1,18]. Recent research in herbal medicine, although limited, has shown the effects of plant botanical on keratinocyte proliferation, the reduction of inflammation, and the stimulation of wound healing $[19,20]$. From a modern biomedical perspective, one could consider that the "balancing of the doshas" that Ayurveda [20,21] aims for may be through actions on the skin and gut microbiome that foster symbiosis.

The fragrance of natural essential oils has been used for centuries therapeutically, and recent studies have shown a positive effect of aromatherapy in reducing stress in prepartum anxiety and overall mental state of patients going through cancer therapy [22]. The protein-based biomarker analysis showed differential effects of these 10 EOs (essential oils) in a pre-inflamed human dermal fibroblast system. Bergamot, cilantro, and spikenard EOs significantly inhibited some inflammatory, tissue remodeling, and immunomodulatory biomarkers, suggesting anti-inflammatory, immunomodulatory, and wound healing properties [23]. Most essential oils and potent herbs have multiple modalities of action on human cells and tissues by influencing cytokines, inflammatory markers, and neuroendocrine pathways (Figure 1) [24]. More research is required to understand how these pathways can relate to the microbiome-host interaction.

\section{Brain}

Neuroendocrine/Neuro-
humoral pathways

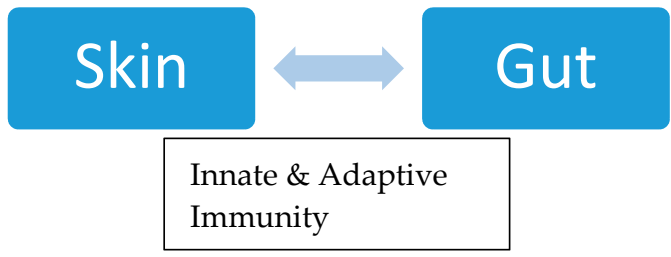

Figure 1. Skin-gut-brain axis.

A list of a few plant botanicals with strong use in Ayurveda and Siddha medicine that have had recent evidence-based clinical studies showing positive skin effects can be found in Table 2.

Table 1. Ayurvedic herbs with recent clinical studies. Ref [25-38].

\begin{tabular}{ccc}
\hline Plant Herb/Extract & Skin Effect & $\begin{array}{c}\text { Gut Effect/Systemic Effect. Mechanism of } \\
\text { Action }\end{array}$ \\
\hline $\begin{array}{c}\text { Amla (Indian Goose Berry) } \\
\text { Phyllanthus emblica }\end{array}$ & $\begin{array}{c}\text { Cooling effect, antioxidant } \\
\text { All parts of the plant and fruit are used for } \\
\text { various symptoms in Ayurvedic medicine } \\
\text { Asconcentrations acid }\end{array}$ & $\begin{array}{c}\text { Aids in digestion when ingested orally, often } \\
\text { used as a post meal digestive drink in } \\
\text { Ayurveda to balance the Dosha imbalance } \\
\text { Maintenance of telomere length is facilitated } \\
\text { by an increase in telomerase activity * }\end{array}$ \\
\hline $\begin{array}{c}\text { Frankincense } \\
\text { Often used as tincture or essential oil } \\
\text { Genus Boswellia in the family Burseraceae }\end{array}$ & $\begin{array}{c}\text { Stimulates dermal fibroblast } \\
\text { Improving tone texture and } \\
\text { clarity }\end{array}$ & $\begin{array}{c}\text { Inflammation, immune response, and tissue } \\
\text { remodeling. Aromatic effects. }\end{array}$ \\
\hline $\begin{array}{c}\text { Rosehip seed } \\
\text { Rosehip, also called rose haw and rose } \\
\text { hep, is the accessory fruit of the rose plant. } \\
\text { Used as oil/herbal Tea/tincture. }\end{array}$ & $\begin{array}{c}\text { Antioxidant, carrier oil for } \\
\text { other essential oils, stimulate } \\
\text { collagen }\end{array}$ & $\begin{array}{c}\text { Anti-inflammatory, high in vitamin A, oleic, } \\
\text { linoleic essential amino acids. }\end{array}$ \\
\hline $\begin{array}{c}\text { Aloe vera gel/juice } \\
\text { Genus: Aloe. }\end{array}$ & $\begin{array}{c}\text { Wound healing and } \\
\text { regeneration }\end{array}$ & Reduces diabetic neuropathy * \\
\hline
\end{tabular}


Table 2. Ayurvedic herbs with recent clinical studies. Ref [25-38].

\begin{tabular}{|c|c|c|}
\hline Plant Herb/Extract & Skin Effect & $\begin{array}{c}\text { Gut Effect/Systemic Effect. Mechanism of } \\
\text { Action }\end{array}$ \\
\hline $\begin{array}{c}\text { Rose, genus Rosa } \\
\text { Rosewater/rose extract/rose essential } \\
\text { oil/tincture }\end{array}$ & $\begin{array}{l}\text { Aromatic, soothing and } \\
\text { cooling effect }\end{array}$ & $\begin{array}{l}\text { Immunomodulation, anti-inflammatory } \\
\text { actions but needs more detailed testing to } \\
\text { confirm. }\end{array}$ \\
\hline $\begin{array}{l}\text { Neem Azadirachta indica } \\
\text { Tree in the mahogany family Meliaceae. }\end{array}$ & $\begin{array}{l}\text { Antibacterial, } \\
\text { anti-inflammatory, antioxidant, } \\
\text { anti-diabetic, antihelminthic }\end{array}$ & Anticancer. Anti-inflammatory \\
\hline Turmeric (Curcuma longa) & $\begin{array}{l}\text { Anti-inflammatory, } \\
\text { antimicrobial } \\
\text { Wound healing }\end{array}$ & $\begin{array}{l}\text { Inflammatory bowel disease } \\
\text { Action via various pathways } \\
\text { Anticancer? }\end{array}$ \\
\hline Grapeseed & $\begin{array}{l}\text { Antioxidant, anti-pigment, } \\
\text { anti-inflammatory }\end{array}$ & $\begin{array}{l}\text { Ingested reduced blood pressure and } \\
\text { cardiovascular risk }\end{array}$ \\
\hline $\begin{array}{l}\text { Sandalwood genus Santalam } \\
\text { Oil/powder }\end{array}$ & $\begin{array}{l}\text { Anti-inflammatory, } \\
\text { anti-pigment }\end{array}$ & $\begin{array}{c}\text { Known to act through multiple immune } \\
\text { pathways. }\end{array}$ \\
\hline
\end{tabular}

\section{Conclusions: Future Considerations for Correlating Plant Botanicals to Surface Microbiome and Their Role in the Concept of "Vibrational Cosmetics" Innovation}

The fast-paced lifestyle of the Western world has increased demand for alternative and holistic practices by the consumer with a new demand and trend for natural and organic skin care. Yoga, meditation, vegan, and Ayurvedic diets have become increasingly popular for the "modern-day yogi." These customers also seek "natural" and "cruelty-free" ingredients in their skin care [39,40]. The global market value for natural cosmetics experienced a positive increase from almost seven billion dollars in 2007 to roughly 15 billion dollars for the year 2017, showing the growing importance of the natural and organic cosmetics market [41].

With increased recognition in the presence and functionality of the microbiome, it is clear that the human body is not what we perceived. The evidence points to the fact that our microbiome proportionally occupies a more predominant structural and functional role in the human body than previously thought. When designing a cosmetic product for the future, we need to make a shift towards understanding and developing formulations that can influence the host-microbiome balance and create a more natural and symbiotic state. For centuries, Eastern medicine has used natural herbs with minimal processing in treatment and rejuvenation with the aim of balance between the patient and their environment. The creation of modern cosmetic formulations influenced by these ancient systems of medicine could be a consideration.

An Ayurvedic herbal preparation that has recently been studied and published is Triphala [42]. It can be ingested as a tea or powder for digestive improvement and gut and liver health. Scientific papers have shown that Triphala has an apoptotic effect on colon cancer stem cells as well as a positive protective effect on dermal fibroblasts $[43,44]$. Triphala has three constituents, Terminalia bellerica, Terminalia chebula, and Emblica officinalis. The role of Triphala and its extract has been emphasized in stimulating neutrophil function. Under stress conditions such as noise, Triphala significantly prevents the elevation of IL-4 levels as well as corrects decreased IL-2 and IFN- $\gamma$ levels. Under the condition of inflammatory stress, its immunosuppressive activity is attributed to its inhibitory action on the complement system, humoral immunity, cell mediated immunity, and mitogen-induced T-lymphocyte proliferation $[45,46]$.

More information on the effects of herbal preparations on the skin and gut microbiome is needed. New research holds great promise in revealing the mechanisms linking dietary patterns with gut microbiota profiles, obesity, inflammation, and disease states. Evidence points to a distinct gut 
microbiome profile in vegan and vegetarian diets that is associated with reduced inflammatory states [47].

As getting closer to nature helps improve mood and stabilize the mind, similarly, a change of dietary habits to more natural organic foods will help to shift to a healthier microbiome of the gut $[48,49]$. The author would like to extrapolate perhaps the important role of having cosmetic ingredients that are plant derived and minimally processed to be more suited for the skin microbiome. One can consider that with less processing, the inherent potent properties could stay intact.

Currently in a high-quality extract these actives are standardized, thus enabling a uniform high-quality extract that will always have the same concentration of actives. In unprocessed plant raw material, the concentration of actives will vary, their availability may be limited, the concentration will most likely be lower when compared to an extract and there is also the risk or degradation of actives in the unprocessed cells due to the presence of degrading enzymes in the unprocessed plant raw material. It will be worth considering that just as the gut microbiome is better suited to natural unprocessed food, one can hypothesize that the skin microbiome is capable of adjusting to the fluctuation of actives in unprocessed ingredients in a similar manner that could lead to a symbiotic state.

Still, further research and publications are required in co-relating the transdermal delivery of botanicals and their effect on the microbiome of the deeper layers of the skin [50]. A simultaneous analysis of the gut and skin microbiota with the use of topically applied botanicals and ingested as tea/herbs would help in correlating any effective action. The natural aroma of the plant botanicals needs to be individually assessed for its effects on cortisol levels and mood stabilizing effects by affecting surface microbiome when applied topically.

We can be more hopeful for a new direction in innovation for cosmetics perhaps personalized to the individual's microbiome signature. The balancing concept of the Dosha as per the science of Ayurveda can be applied to cosmetics to achieve a balance/symbiosis of the surface microbiome using natural plant botanicals. Evidence points to the fact that the skin functions as a third brain, the second being the gut [51]. Coining the term "vibrational cosmetics" for this new dimension and approach to cosmetics innovation is plausible. Based on this new concept of vibrational cosmetics, one can envision the future of skin care as not only making one look good, but also feel good. The underpinnings of the timeless idea that healthy eating is the key to glowing skin may now be closer to being scientifically understood through the skin-gut axis.

Conflicts of Interest: The author declares no conflict of interest.

\section{References}

1. Beri, K. Skin microbiome and host immunity applications in regenerative cosmetics and transdermal drug delivery. Future Sci. OA 2018. [CrossRef]

2. Belkaid, Y.; Tamoutounour, S. The influence of skin microorganisms on cutaneous immunity. Nat. Rev. Immunol. 2016, 16, 353-366. [CrossRef] [PubMed]

3. Sender, R.; Fuchs, S.; Milo, R. Revised estimates for the number of human and bacteria cells in the body. PLoS Biol. 2016, 14, e1002533. [CrossRef] [PubMed]

4. Belkaid, Y.; Segre, J.A. Dialogue between skin microbiota and immunity. Science 2014, 346, $954-959$. [CrossRef] [PubMed]

5. Zeeuwen, P.L.; Boekhorst, J.; Van den Bogaard, E.H.; de Koning, H.D.; van de Kerkhof, P.M.; Saulnier, D.M.; van Swam, I.I.; van Hijum, S.A.; Kleerebezem, M.; Schalkwijk, J.; et al. Microbiome dynamics of human epidermis following skin barrier disruption. Genome Biol. 2012, 13, R101. [CrossRef] [PubMed]

6. Craig, J.M. Atopic dermatitis and the intestinal microbiota in humans and dogs. Vet. Med. Sci. 2016, 2, 95-105. [CrossRef] [PubMed]

7. Gupta, M.A.; Jarosz, P.; Gupta, A.K. Posttraumatic stress disorder (PTSD) and the dermatology patient. Clin. Dermatol. 2017, 35, 260-266. [CrossRef] [PubMed] 
8. Codoñer, F.M.; Ramírez-Bosca, A.; Climent, E.; Carrión-Gutierrez, M.; Guerrero, M.; Pérez-Orquín, J.M.; Horga de la Parte, J.; Genovés, S.; Ramón, D.; Navarro-López, V.; et al. Gut microbial composition in patients with psoriasis. Sci. Rep. 2018, 8, 3812. [CrossRef] [PubMed]

9. Clapp, M.; Aurora, N.; Herrera, L.; Bhatia, M.; Wilen, E.; Wakefield, S. Gut microbiota's effect on mental health: The gut-brain axis. Clin. Pract. 2017, 7, 987. [CrossRef] [PubMed]

10. Clark, A.K.; Haas, K.N.; Sivamani, R.K. Edible plants and their influence on the gut microbiome and acne. Int. J. Mol. Sci. 2017, 18, 1070. [CrossRef] [PubMed]

11. Glick-Bauer, M.; Yeh, M.-C. The health advantage of a vegan diet: Exploring the gut microbiota connection. Nutrients 2014, 6, 4822-4838. [CrossRef] [PubMed]

12. Singh, R.K.; Chang, H.-W.; Yan, D.; Lee, K.M.; Ucmak, D.; Wong, K.; Abrouk, M.; Farahnik, B.; Nakamura, M.; Zhu, T.H.; et al. Influence of diet on the gut microbiome and implications for human health. J. Transl. Med. 2017, 15, 73. [CrossRef] [PubMed]

13. Kelly, J.R.; Minuto, C.; Cryan, J.F.; Clarke, G.; Dinan, T.G. Cross talk: The microbiota and neurodevelopmental disorders. Front. Neurosci. 2017, 11, 490. [CrossRef] [PubMed]

14. Trehan, S.; Michniak-Kohn, B.; Beri, K. Plant stem cells in cosmetics: Current trends and future directions. Future Sci. OA 2017, 3, FSO226. [CrossRef] [PubMed]

15. Morus, M.; Baran, M.; Rost-Roszkowska, M.; Skotnicka-Graca, U. Plant stem cells as innovation in cosmetics. Acta Pol. Pharm. 2014, 71, 701-707. [PubMed]

16. Korkina, L.G.; Mayer, W.; de Luca, C. Meristem plant cells as a sustainable source of redox actives for skin rejuvenation. Biomolecules 2017, 7, 40. [CrossRef] [PubMed]

17. Lin, T.K.; Zhong, L.; Santiago, J.L. Anti-inflammatory and skin barrier repair effects of topical application of some plant oils. Int. J. Mol. Sci. 2017, 19, 70. [CrossRef] [PubMed]

18. Beri, K. A future perspective for regenerative medicine, understanding the concept of vibrational medicine. Future Sci. OA 2018, 4. [CrossRef] [PubMed]

19. Gunasekara, T.; Radhika, N.; Ragunathan, K.K.; Gunathilaka, D.; Weerasekera, M.M.; Hewageegana, H.; Arawwawala, L.A.D.M.; Fernando, S. Determination of antimicrobial potential of five herbs used in Ayurveda Practices against Candida albicans, Candida parapsilosis and methicillin resistant Staphylococcus aureus. Anc. Sci. Life 2017, 36, 187-190. [CrossRef] [PubMed]

20. Mukherjee, P.K.; Harwansh, R.K.; Bahadur, S.; Banerjee, S.; Kar, A.; Chanda, J.; Biswas, S.; Ahmmed, S.M.; Katiyar, C.K. Development of Ayurveda-Tradition to trend. J. Ethnopharmacol. 2017, 197, 10-24. [CrossRef] [PubMed]

21. Sarkar, C.; Webster, C.; Gallacher, J. Residential greenness and prevalence of major depressive disorders: A cross-sectional, observational, associational study of 94879 adult UK Biobank participants. Lancet Planet. Health 2018, 2, e162-e173. [CrossRef]

22. PDQ Integrative, Alternative, and Complementary Therapies Editorial Board. Aromatherapy and Essential Oils (PDQ®): Health Professional Version. Available online: http:/ / www.ncbi.nlm.nih.gov/books/NBK65874/ (accessed on 24 March 2018).

23. Orchard, A.; van Vuuren, S.F.; Viljoen, A.; Kamatou, G. The in vitro antimicrobial evaluation of commercially essential oils and their combinations against acne. Int. J. Cosmet. Sci. 2018. [CrossRef] [PubMed]

24. Han, X.; Beaumont, C.; Stevens, N. Chemical composition analysis and in vitro biological activities of ten essential oils in human skin cells. Biochem. Open 2017, 5, 1-7. [CrossRef] [PubMed]

25. Concha, J.; Soto, C.; Chamy, R.; Zúñiga, M.E. Effect of rosehip extraction process on oil and defatted meal physicochemical properties. J. Am. Oil Chem. Soc. 2006, 83, 771-775. [CrossRef]

26. Memariani, Z.; Moeini, R.; Hamedi, S.S.; Gorji, N.; Mozaffarpur, S.A. Medicinal plants with antithrombotic property in Persian medicine: A mechanistic review. J. Thromb. Thrombolysis 2018, 45, 158-179. [CrossRef] [PubMed]

27. Reis, D.; Jones, T.T. Frankincense essential oil as a supportive therapy for cancer-related fatigue: A case study. Holist. Nurs. Pract. 2018, 32, 140-142. [CrossRef] [PubMed]

28. Han, X.; Rodriguez, D.; Parker, T.L. Biological activities of frankincense essential oil in human dermal fibroblasts. Biochim. Open 2017, 4, 31-35. [CrossRef] [PubMed]

29. Haroyan, A.; Mukuchyan, V.; Mkrtchyan, N.; Minasyan, N.; Gasparyan, S.; Sargsyan, A.; Narimanyan, M.; Hovhannisyan, A. Efficacy and safety of curcumin and its combination with boswellic acid in osteoarthritis: 
A comparative, randomized, double-blind, placebo-controlled study. BMC Complement. Altern. Med. 2018, 18, 7. [CrossRef] [PubMed]

30. Burusapat, C.; Supawan, M.; Pruksapong, C.; Pitiseree, A.; Suwantemee, C. Topical aloe vera gel for accelerated wound healing of split-thickness skin graft donor sites: A double-blind, randomized, controlled trial and systematic review. Plast. Reconstr. Surg. 2018. [CrossRef] [PubMed]

31. Arora, M.K.; Sarup, Y.; Tomar, R.; Singh, M.; Kumar, P. Amelioration of diabetes-induced diabetic nephropathy by aloe vera: Implication of oxidative stress and hyperlipidemia. J. Diet. Suppl. 2018, 1-18. [CrossRef] [PubMed]

32. Sundaram, D.; Narayanan, R.K.; Vadakkepurayil, K. A comparative evaluation on antimicrobial effect of honey, neem leaf extract and sodium hypochlorite as intracanal irrigant: An ex-vivo study. J. Clin. Diagn. Res. 2016, 10, ZC88-ZC91. [CrossRef] [PubMed]

33. Hao, F.; Kumar, S.; Yadav, N.; Chandra, D. Neem components as potential agents for cancer prevention and treatment. Biochim. Biophys. Acta 2014, 1846, 247-257. [CrossRef] [PubMed]

34. McCann, M.J.; Johnston, S.; Reilly, K.; Men, X.; Burgess, E.J.; Perry, N.B.; Roy, N.C. The effect of turmeric (Curcuma longa) extract on the functionality of the solute carrier protein 22 A4 (SLC22A4) and interleukin-10 (IL-10) variants associated with inflammatory bowel disease. Nutrients 2014, 6, 4178-4190. [CrossRef] [PubMed]

35. Bagchi, D.; Swaroop, A.; Preuss, H.G.; Bagchi, M. Free radical scavenging, antioxidant and cancer chemoprevention by grape seed proanthocyanidin: An overview. Mutat. Res. 2014, 768, 69-73. [CrossRef] [PubMed]

36. Moy, R.L.; Levenson, C. Sandalwood album oil as a botanical therapeutic in dermatology. J. Clin. Aesthet. Dermatol. 2017, 10, 34-39. [PubMed]

37. Muthu, P.R.; Bobby, Z.; Sankar, P.; Vickneshwaran, V.; Jacob, S.E. Amla (Emblica officinalis) improves hepatic and renal oxidative stress and the inflammatory response in hypothyroid female wistar rats fed with a high-fat diet. J. Basic Clin. Physiol. Pharmacol. 2018, 29, 175-184. [CrossRef] [PubMed]

38. Yadav, S.S.; Singh, M.K.; Singh, P.K.; Kumar, V. Traditional knowledge to clinical trials: A review on therapeutic actions of Emblica officinalis. Biomed. Pharmacother. 2017, 93, 1292-1302. [CrossRef] [PubMed]

39. Beri, K. The impact of the "yogic lifestyle" on cancer prognosis and survival: Can we target cancer stem cells with yoga? Int. J. Yoga 2017, 10, 95-98. [CrossRef] [PubMed]

40. Beri, K. Breathing to younger skin: "reversing the molecular mechanism of skin aging with yoga.". Future Sci. OA 2016, 2, FSO122. [CrossRef] [PubMed]

41. Cosmetics Industry-Statistics \& Facts. Available online: https://www.statista.com/topics/3137/cosmeticsindustry/ (accessed on 12 October 2017).

42. Peterson, C.T.; Sharma, V.; Uchitel, S.; Denniston, K.; Chopra, D.; Mills, P.J.; Peterson, S.N. Prebiotic Potential of Herbal Medicines Used in Digestive Health and Disease. J. Altern. Complement. Med. 2018. [CrossRef] [PubMed]

43. Peterson, C.T.; Denniston, K.; Chopra, D. Therapeutic uses of Triphala in Ayurvedic medicine. J. Altern. Complement. Med. 2017, 23, 607-614. [CrossRef] [PubMed]

44. Varma, S.R.; Sivaprakasam, T.O.; Mishra, A.; Kumar, L.S.; Prakash, N.S.; Prabhu, S.; Ramakrishnan, S. Protective effects of Triphala on dermal fibroblasts and human keratinocytes. PLoS ONE 2016, 11, e0145921. [CrossRef] [PubMed]

45. Vadde, R.; Radhakrishnan, S.; Reddivari, L.; Vanamala, J.K.P. Triphala Extract Suppresses Proliferation and Induces Apoptosis in Human Colon Cancer Stem Cells via Suppressing c-Myc/Cyclin D1 and Elevation of Bax/Bcl-2 Ratio. BioMed Res. Int. 2015, 2015, 649263. [CrossRef] [PubMed]

46. Belapurkar, P.; Goyal, P.; Tiwari-Barua, P. Immunomodulatory Effects of Triphala and its Individual Constituents: A Review. Indian J. Pharm. Sci. 2014, 76, 467-475. [PubMed]

47. O'Neill, C.A.; Monteleone, G.; McLaughlin, J.T.; Paus, R. The gut-skin axis in health and disease: A paradigm with therapeutic implications. BioEssays 2016, 38, 1167-1176. [CrossRef] [PubMed]

48. Denda, M.; Tekai, K.; Denda, S. How does epidermal pathology interact with mental state? Med. Hypotheses 2013, 80, 194-196. [CrossRef] [PubMed]

49. Prescott, S.L.; Larcombe, D.L.; Logan, A.C.; West, C.; Burks, W.; Caraballo, L.; Levin, M.; Van Etten, E.; Horwitz, P.; Kozyrskyj, A.; et al. The skin microbiome: Impact of modern environments on skin ecology, 
barrier integrity, and systemic immune programming. World Allergy Organ. J. 2017, 10, 29. [CrossRef] [PubMed]

50. Beri, K.; Milgraum, S.S. Neocollagenesis in deep and superficial dermis by combining fractionated $Q$-switched ND: YAG 1064-nm with topical plant stem cell extract and N-acetyl glucosamine: Open case series. J. Drugs Dermatol. 2015, 14, 1342-1346. [PubMed]

51. Denda, M. Epidermis as the third brain. Dermatol. Sin. 2015, 33, 70-73. [CrossRef]

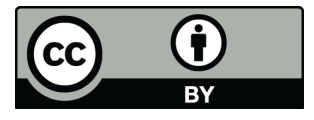

(c) 2018 by the author. Licensee MDPI, Basel, Switzerland. This article is an open access article distributed under the terms and conditions of the Creative Commons Attribution (CC BY) license (http://creativecommons.org/licenses/by/4.0/). 